See discussions, stats, and author profiles for this publication at: https://www.researchgate.net/publication/282047062

\title{
Closing Domestic Nutrient Cycles Using Microalgae
}

Article in Environmental Science \& Technology · September 2015

DOI: 10.1021/acs.est.5b02858

\section{CITATIONS}

38

8 authors, including:

Tania V. Fernandes

Netherlands Institute of Ecology (NIOO-KNAW)

18 PUBLICATIONS 565 CITATIONS

SEE PROFILE

Yixing Sui

University of Greenwich

15 PUBLICATIONS 168 CITATIONS

SEE PROFILE
READS

484

Rabin Shrestha

Winrock International

2 PUBLICATIONS 81 CITATIONS

SEE PROFILE

Bil

Gustavo Papini G. de Sousa

University of Antwerp

5 PUBlications 67 Citations

SEE PROFILE

Some of the authors of this publication are also working on these related projects:

Cognitive consequences of natural variation in learning in parasitic wasps View project

Boosting the efficacy of biological control agents of citrus mealybugs through olfactory conditioning View project 


\title{
Closing Domestic Nutrient Cycles Using Microalgae
}

\author{
Tânia Vasconcelos Fernandes, ${ }^{* \dagger}$ Rabin Shrestha, ${ }^{\dagger}$ Yixing Sui, ${ }^{\dagger}, \#$ Gustavo Papini, ${ }^{\dagger}$ Grietje Zeeman, ${ }^{\S}$
} Louise E. M. Vet, ${ }^{\|}$Rene H. Wijffels, ${ }^{\ddagger}, \perp$ and Packo Lamers

${ }^{\dagger}$ Department of Aquatic Ecology, Netherlands Institute of Ecology (NIOO-KNAW), P.O. Box 50, 6700 AB Wageningen, The Netherlands

${ }^{\ddagger}$ Bioprocess Engineering, AlgaePARC, Wageningen University, P.O. Box 16, 6700 AA Wageningen, The Netherlands

${ }^{\S}$ Sub-department of Environmental Technology, Wageningen University, P.O. Box 8129, 6700 EV Wageningen, The Netherlands

"Department of Terrestrial Ecology, Netherlands Institute of Ecology (NIOO-KNAW), P.O. Box 50, 6700 AB Wageningen, The Netherlands

${ }^{\perp}$ University of Nordland, Faculty of Biosciences and Aquaculture, N-8049, Bodø, Norway

ABSTRACT: This study demonstrates that microalgae can effectively recover all $\mathrm{P}$ and $\mathrm{N}$ from anaerobically treated black water (toilet wastewater). Thus, enabling the removal of nutrients from the black water and the generation of a valuable algae product in one step. Screening experiments with green microalgae and cyanobacteria showed that all tested green microalgae species successfully grew on anaerobically treated black water. In a subsequent controlled experiment in flat-panel photobioreactors, Chlorella sorokiniana was able to remove $100 \%$ of the phosphorus and nitrogen from the medium. Phosphorus was depleted within 4 days while nitrogen took 12 days to reach depletion. The phosphorus and nitrogen removal rates during the initial linear growth phase were 17 and $122 \mathrm{mg} \cdot \mathrm{L}^{-1} \cdot \mathrm{d}^{-1}$, respectively. After this

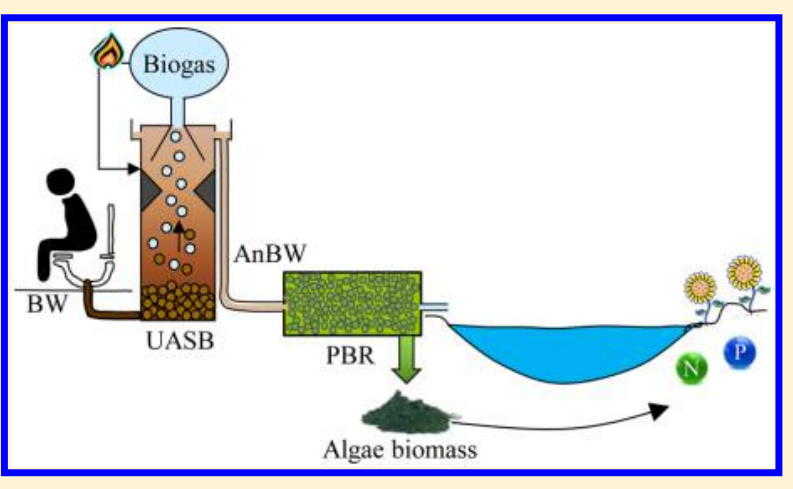
initial phase, the phosphorus was depleted. The nitrogen removal rate continued to decrease in the second phase, resulting in an overall removal rate of $80 \mathrm{mg} \cdot \mathrm{L}^{-1} \cdot \mathrm{d}^{-1}$. The biomass concentration at the end of the experiment was $11.5 \mathrm{~g} \cdot \mathrm{L}^{-1}$, with a $\mathrm{P}$ content of approximately $1 \%$ and a $\mathrm{N}$ content of $7.6 \%$. This high algal biomass concentration, together with a relatively short P recovery time, is a promising finding for future post-treatment of black water while gaining valuable algal biomass for further application.

\section{INTRODUCTION}

As the world's population increases so does the amount of wastewater produced. Wastewater has always been characterized as a polluted stream, and therefore the 20th and 21 st century wastewater treatment plants focus on the removal of the organic and inorganic pollutants. However, modern society has realized that these organic and inorganic compounds are actually valuable products that can be recovered and recycled back into our resource demanding society. In current centralized sanitation systems urine and faeces are greatly diluted with the remaining household wastewater, rainwater, and small-scale industrial wastewater, therefore making it harder to recover its valuable compounds. Hence, the current challenge is to rethink our present wastewater treatment system and provide the technology to not only remove organic and inorganic compounds but also recover them in a sustainable and highly efficient manner.

New sanitation concepts, where black water (BW - toilet wastewater) and gray water (GW - shower/washing wastewater) are separated at the source, conserve organic and inorganic compounds in a smaller volume which facilitates recovery. ${ }^{1}$ The Netherlands Institute of Ecology (NIOOKNAW) in The Netherlands has implemented such a source separated system in its new building. The BW is vacuum collected using only $1 \mathrm{~L}$ of water per flush and then treated in a UASB (upflow anaerobic sludge blanket), where the carbon is converted into biogas, a green energy source. Anaerobic treatment of concentrated black water is proven technology for treating high-strength wastewater. ${ }^{2}$

The remaining effluent, known as anaerobically treated black water (AnBW), contains the major part of the nutrients. One of these nutrients is phosphorus. The world's main source of phosphorus is phosphate rock which, at the current extraction rate, will be depleted in the coming century. ${ }^{3}$ Of all phosphorus and nitrogen produced in a household's wastewater, urine contains $40 \%$ of the phosphorus and $69 \%$ of the nitrogen, while faeces contains $28 \%$ of the phosphorus and $13 \%$ of the nitrogen. ${ }^{4}$ If one is able to recover all the phosphorus from faeces and urine, human excreta could supply $22 \%$ of the world phosphorus demand. ${ }^{5}$

Received: June 11, 2015

Revised: September 10, 2015

Accepted: September 21, 2015 
Table 1. Average Characteristics of the AnBW Used for the Experiments ${ }^{a}$

\begin{tabular}{|c|c|c|c|c|}
\hline $\mathrm{pH}$ & Total nitrogen $\left(\mathrm{gTN} \cdot \mathrm{L}^{-1}\right)$ & Ammonia $\left(\mathrm{gNH}_{4}^{+}-\mathrm{N} \cdot \mathrm{L}^{-1}\right)$ & Total phosphorus (mgTP $\left.\cdot \mathrm{L}^{-1}\right)$ & Phosphate $\left(\mathrm{mgPO}_{4}-\mathrm{P} \cdot \mathrm{L}^{-1}\right)$ \\
\hline $7.6 \pm 0.2$ & $1.21 \pm 0.01$ & $1.07 \pm 0.08$ & $105.2 \pm 3.9$ & $73 \pm 10$ \\
\hline
\end{tabular}

Phosphorus can be recovered from concentrated wastewater by struvite precipitation. However, this process requires a high $\mathrm{pH}(>8)$ and extra addition of magnesium to form the mineral. ${ }^{6}$ Moreover, even though struvite incorporates nitrogen, the amount of nitrogen that is recovered via this technology is limited. A very promising alternative to recover phosphorus, and nitrogen at the same time, is by microalgae growth.

Microalgae are becoming increasingly interesting as a renewable energy sources due to their fast growth and noncompetitive nature with regard to food production. ${ }^{7}$ When sufficient light and carbon dioxide are supplied, microalgae biomass production and nutrient uptake are high. The algae biomass could be directly used as a fertilizer, ${ }^{8}$ therefore returning the nutrients back to the soil to grow crops, thereby closing the nutrient cycle. The algae biomass could also be used as a resource for a diversity of added-value products.

Most studies on $\mathrm{N}$ and $\mathrm{P}$ removal by microalgae deal with low nutrient concentrations, from drinking water, fresh water, sewer, or waste streams, such as animal manure, that were diluted prior to cultivation. ${ }^{9-13}$ The choice of diluting is justified by the difficulty of growing microalgae at high ammonia concentrations, which has been reported to inhibit microalgae growth. ${ }^{14}$ However, when the $\mathrm{pH}$ is kept neutral, ammonia inhibition is prevented, and growth of algae on the nutrient-rich stream is possible, resulting in high biomass concentrations. The high biomass concentration is an economic advantage as it reduces the overall costs of harvesting, which is one of the main reasons why microalgae growth on wastewater is still not applied at full scale. ${ }^{15-17}$ Recently, one study has shown growth of microalgae on nutrient-rich human urine. However, for higher nitrogen removal rates, adjustment of the $\mathrm{N}: \mathrm{P}$ ratio and addition of magnesium was necessary. ${ }^{18} \mathrm{AnBW}$ has higher concentrations of magnesium than urine and a more favorable $\mathrm{N}: \mathrm{P}$ ratio for algae growth $(\sim 45: 1$ for urine vs $\sim 30: 1$ for AnBW). The high N:P ratio of AnBW is still higher than the 16:1 N:P ratio usually reported for phytoplankton, ${ }^{19}$ and so the challenge remains to reach full $\mathrm{N}$ and $\mathrm{P}$ removal. In addition, the darker color of the AnBW, which is attributed to the humic matter, has been reported to affect microalgae growth both negatively, by absorbing part of the available light, and positively, by serving as an energy source and stimulating better growth. ${ }^{20,21}$

The goal of the present work is to explore the potential of microalgae for phosphorus and nitrogen recovery from AnBW and present a proof of principle that microalgae cultivation can be added as a post-treatment technology after anaerobic treatment.

\section{MATERIALS AND METHODS}

Culture Medium. The culture medium used for microalgae growth was AnBW from a UASB reactor fed with vacuumcollected black water, operated in Sneek, The Netherlands at 25 ${ }^{\circ} \mathrm{C}$ and 8.3 days HRT. All containers of AnBW were stored at 4 ${ }^{\circ} \mathrm{C}$ until use. The average characteristics of the AnBW are presented in Table 1.

The translucent brownish color of AnBW does not negatively affect the microalgae cultivation, as is often suggested, ${ }^{22}$ because the light attenuation coefficient is much higher for a typical outdoor microalgae culture (between 200 and $2000 \mathrm{~m}^{-1}$ in clear growth medium, depending on the microalgae concentration) than for AnBW (between 70 and $140 \mathrm{~m}^{-1}$, depending on the amount of suspended solids of AnBW). This means that at high density microalgae cultures, most of the light will be absorbed by the microalgae cells and not by the suspended solids.

On the other hand, AnBW's naturally high calcium carbonate $\left(\sim 4.6 \mathrm{~g} \mathrm{CaCO}_{3} \cdot \mathrm{L}^{-1}\right)$ and high ammonia concentration $(\sim 1 \mathrm{~g}$ $\left.\mathrm{NH}_{4}{ }^{+}-\mathrm{N} \cdot \mathrm{L}^{-1}\right)$ do pose challenges for microalgae cultivation and demand for tight $\mathrm{pH}$ control. More specifically, the high carbonate concentration requires constant aeration with high $\mathrm{CO}_{2}$ concentrations. Otherwise, the carbonate in the AnBW would leave the reactor via the gas stream in the form of $\mathrm{CO}_{2}$ (to restore chemical equilibrium between dissolved carbon species and gaseous $\mathrm{CO}_{2}$ ), thereby causing an increase in $\mathrm{pH}$. Next to a direct negative impact of high $\mathrm{pH}$ on microalgal growth, such a $\mathrm{pH}$ increase would cause the dissociation of the ammonium ion $\left(\mathrm{NH}_{4}^{+}\right)$to toxic $\mathrm{NH}_{3}$. Due to the high ammonia concentration of the $\mathrm{AnBW}$, an $\mathrm{NH}_{3}$ concentration higher than the threshold value of $30 \mathrm{mg} \mathrm{NH}-\mathrm{N} \cdot \mathrm{L}^{-1}$ reported for inhibition of green microalgae growth ${ }^{14}$ will be reached at a $\mathrm{pH}$ higher than 7.7 for $25^{\circ} \mathrm{C}$ or 7.3 for $37^{\circ} \mathrm{C}$. Therefore, in all experiments the $\mathrm{pH}$ was tightly controlled to neutrality and the reactors were aerated with pressurized air enriched with $3-10 \%$ $\mathrm{CO}_{2}$ depending on the experimental setup.

Microalgae Species. Chlorella vulgaris UTEX 26, Scenedesmus obliquus CCAP276/3a, Synechococcus elongates SAG 8979, Anabaena flos-aquae CCAP1446/1C, and Synechocystis sp. $6803 \mathrm{WT}$ were obtained from the algal collection of NIOOKNAW. Chlorella sorokiniana CCAP 211/8K was obtained from CCAP (Oban, UK). All cultures were maintained under aseptic conditions in a WC medium ${ }^{23}$ and incubated (Sanyo, MLR-350) at $18{ }^{\circ} \mathrm{C}$ with $14 \mathrm{~h}$ of illumination $\left(100 \mu \mathrm{mol} \cdot \mathrm{m}^{-2}\right.$. $\mathrm{s}^{-1}$ ) per day.

Experimental Setup for Microalgae Screening. The six different microalgae species were cultivated in batch mode in $300 \mathrm{~mL}$ Erlenmeyer flasks placed in an incubator with a shaking platform (Sanyo Gallenkamp PLC). The incubator was operated at $25{ }^{\circ} \mathrm{C}, 100 \mathrm{rpm}$. The incubator was aerated with $3 \% \mathrm{CO}_{2}$ enriched air at a rate of $0.5 \mathrm{~L} \cdot \mathrm{min}^{-1}$. All experiments were carried out in triplicate.

The $\mathrm{pH}$ of the AnBW was kept at neutrality by the addition of $75 \mathrm{mM}$ HEPES buffer that was added before algal inoculation. Moreover, the $\mathrm{pH}$ was measured daily with a $\mathrm{pH}$ meter (WTW- 330i) and deviation from neutrality was kept lower than 0.2 units with the addition of either $1 \mathrm{M} \mathrm{HCl}$ or $1 \mathrm{M}$ $\mathrm{NaOH}$. Each flask was filled with $120 \mathrm{~mL}$ of AnBW and inoculated with 10000 cells $\cdot \mathrm{mL}^{-1}$ of one of the six algae species. After the inoculation, the flasks were placed and kept in the incubator throughout the whole experiment. The flask positions in the incubator were daily randomly rotated in order to provide an equal average light intensity of $175 \mu \mathrm{mol} \cdot \mathrm{m}^{-2} \cdot \mathrm{s}^{-1}$ to each flask. Samples were taken every 2-3 days to follow the algal growth and the nutrient depletion. 
Experimental Setup for Microalgae $\mathrm{N}$ and $\mathrm{P}$ Removal in Controlled Photobioreactors. Three flat panel photobioreactors $(\mathrm{PBRs})^{24}$ were operated under batch conditions as replicates. Each PBR contained a total liquid volume of $380 \mathrm{~mL}$, a light path of $14 \mathrm{~mm}$, and a total illuminated area of $0.027 \mathrm{~m}^{2}$. The content was homogeneously mixed by air bubbling enriched with $10 \% \mathrm{CO}_{2}$ at a flow of $400 \mathrm{~mL} \cdot \mathrm{min}^{-1}(40 \mathrm{~mL}$. $\mathrm{min}^{-1} \mathrm{CO}_{2}$ and $360 \mathrm{~mL} \cdot \mathrm{min}^{-1}$ air). Each PBR was filled with AnBW and inoculated with 175000 cells $\cdot \mathrm{mL}^{-1}$ of Chlorella sorokiniana. The temperature was kept at $37{ }^{\circ} \mathrm{C}$ with the $\mathrm{pH}$ at $7.0 \pm 0.7$, which are the optimal growth conditions for Chlorella sorokiniana. $^{25}$ The light intensity, averaged over the entire culture volume (see Calculations section), was kept at 100 $\mu \mathrm{mol} \cdot \mathrm{m}^{-2} \cdot \mathrm{s}^{-1}$ for the first 5 days and at $150 \mu \mathrm{mol} \cdot \mathrm{m}^{-2} \cdot \mathrm{s}^{-1}$ for the remaining experimental time.

Chemical Analyses. Samples for $\mathrm{NH}_{4}{ }^{+}-\mathrm{N}, \mathrm{PO}_{4}{ }^{3-}-\mathrm{P}$, $\mathrm{NO}_{3}{ }^{-}-\mathrm{N}$, and $\mathrm{NO}_{2}{ }^{-}-\mathrm{N}$ analysis were centrifuged (Sartorius 1$15 \mathrm{P})$ at $14000 \mathrm{rpm}$ for $10 \mathrm{~min}$. The supernatant was filtered through a $0.2 \mu \mathrm{m}$ cellulose acetate filter (chroafil ca-20/25) and measured in a Seal QUAATRO Auto Analyzer (Beun de Ronde, Abcoude) according to standard methods. ${ }^{26}$ Chlorophyll $a$ fluorescence was measured with a Phyto-PAM (Heinz Walz, Effeltrich, Germany) and algal biovolume (algal hold-up) with a CASY1Model TTC system (Schärfe System $\mathrm{GmbH}$ ). At the end of the experiment, the algal dry weight (DW) and elemental composition of the algal biomass (CNP) were determined according to standard methods. ${ }^{26}$ The elemental composition was measured with an Elemental Analyzer (Flash 2000, Interscience Breda) and a Seal QUAATRO Auto Analyzer.

Calculations. Free ammonia $\left(\mathrm{NH}_{3}\right)$ was calculated according to Fernandes et al. (2012). ${ }^{27}$ Average light intensity $\left(I_{\text {avg }}\right)$ inside the entire culture was calculated according to Santos et al. (2014). ${ }^{28}$ The biomass yield on light $\left(Y_{\mathrm{x}, \mathrm{E}}\right)$ in $\mathrm{g}$ mol photon ${ }^{-1}$ during any given time interval was calculated by dividing the total amount of biomass produced during that time interval by the total amount of light falling on the photobioreactor in the same time interval, as described by Cuaresma et al. (2011). ${ }^{29}$ Only photons from the photosynthetically active radiation (PAR) are taken into account in this publication. The amount of nitrogen and phosphorus taken up by the microalgae was calculated based on the measured amount of dry algal biomass produced at the end of the experiment and on the $\mathrm{N}$ and $\mathrm{P}$ mass percentages of this biomass. The amounts of nitrogen and phosphorus that were removed from the AnBW were calculated as the concentration difference between the start and end of the experiment, for $\mathrm{NH}_{4}-\mathrm{N}$ and $\mathrm{PO}_{4}-\mathrm{P}$ in the culture supernatant, respectively. In cases where the removed amounts of $\mathrm{N}$ and $\mathrm{P}$ were compared with the amounts of $\mathrm{N}$ and $\mathrm{P}$ taken up by the algae, corrections were made for the $\mathrm{N}$ and $\mathrm{P}$ removed during sampling.

$\mathrm{P}$ and $\mathrm{N}$ removal followed zero-order kinetics from the beginning of microalgae growth to $\mathrm{P}$ depletion (from day 2 to 8). $\mathrm{N}$ removal remained mostly as zero-order up to the end of the run, while $\mathrm{P}$ only followed zero-order kinetics after recuperation of the cells (from day 11 to 14).

\section{RESULTS AND DISCUSSION}

Microalgae Screening. Three out of the six tested species successfully grew on AnBW, namely the green microalgae $C$. vulgaris, $S$. obliquus, and $C$. sorokiniana. The cyanobacteria species $S$. elongates, $A$. flos-aquae, and $S$. sp. showed no growth (Figure 1). The lack of growth by these cyanobacteria might be

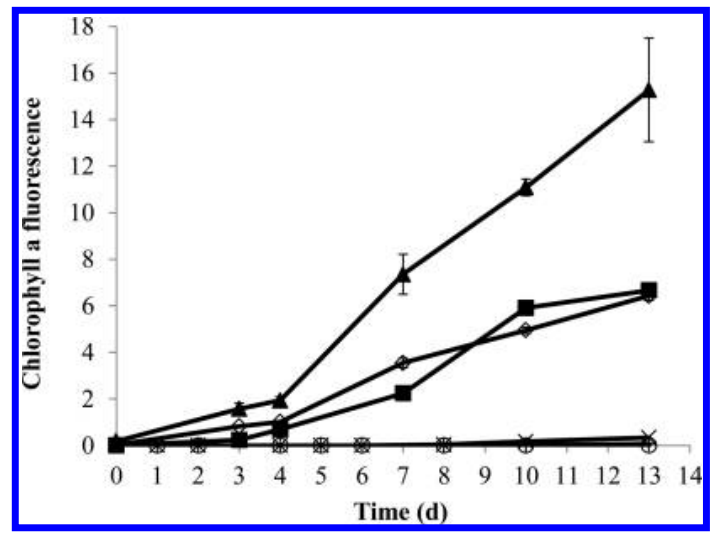

Figure 1. Chlorophyll $a$ fluorescence of all algae species tested in time. C. sorokiniana $(\mathbf{\Lambda})$, C. vulgaris $(\mathbf{\square})$, S. obliquus $(\diamond)$, S. elongates $(O)$, A. flos-aquae $(+)$, and $S$. sp $(\times)$. Error bars represent standard deviation between triplicates.

due to photoinhibition just after inoculation ${ }^{30,31}$ or due to something in the AnBW composition that inhibited the cyanobacterial growth. This needs further investigation.

The three microalgae species that did successfully grow on AnBW reached biomass concentrations of about $4 \mathrm{~g}$ dry weight. $\mathrm{L}^{-1}$ after 13 days (Table 2). Average biomass productivities over the entire cultivation period were $0.28,0.33$, and $0.34 \mathrm{~g}$ dry weight $\cdot \mathrm{L}^{-1} \cdot \mathrm{d}^{-1}$ for $C$. vulgaris, C. sorokiniana, and $S$. obliquus, respectively. The biomass productivity was quite constant throughout the entire experiment for each species, as can be concluded from the relatively linear increase in chlorophyll $a$ fluorescence over time (Figure 1).

All three species showed an $\mathrm{NH}_{4}{ }^{+}-\mathrm{N}$ removal of about $30 \%$, while the $\mathrm{PO}_{4}-\mathrm{P}$ removal varied greatly, between $22 \%$ and $93 \%$ (Table 2). The $\mathrm{NH}_{4}{ }^{+}-\mathrm{N}$ removed from the medium was all taken up by the algae biomass, with $102 \%, 103 \%$, and $104 \%$ of the removed $\mathrm{N}$ ending up in the biomass, as explained in the Calculations section, for C. vulgaris, C. sorokiniana, and $S$. obliquus, respectively. The slightly higher than $100 \%$ values was most likely due to measurement error. For the removed $\mathrm{PO}_{4}-$ P, $119 \%, 118 \%$, and $136 \%$ ended up in the biomass for $C$. vulgaris, C. sorokiniana, and S. obliquus, respectively, indicating that there must have been release of $\mathrm{P}$ from the suspended solids of the AnBW, as has been reported in the literature. Based on the initial TP $\left(105.2 \mathrm{mg} \cdot \mathrm{L}^{-1}\right)$ it could be calculated that this release of $\mathrm{P}$ and subsequent uptake by the algae was partial and some $\mathrm{P}$ must have remained in the solids by the end of the experiment.

The removal rates of $\mathrm{N}$ and $\mathrm{P}$ for the three species were 13 , 17 , and $16 \mathrm{mg} \mathrm{N} \cdot \mathrm{L}^{-1} \cdot \mathrm{d}^{-1}$ and $1.4,2.1$, and $5.9 \mathrm{mg} \mathrm{P} \cdot \mathrm{L}^{-1} \cdot \mathrm{d}^{-1}$ for C. vulgaris, C. sorokiniana, and S. obliquus, respectively. These values are in accordance with literature on microalgae growth under low light in various cultivation systems with different geometries and different operating conditions, varying from 0.5 to $44 \mathrm{mg} \mathrm{N} \cdot \mathrm{L}^{-1} \cdot \mathrm{d}^{-1}$ and from 1.8 to $9.4 \mathrm{mg} \mathrm{P} \cdot \mathrm{L}^{-1} \cdot \mathrm{d}^{-1} \cdot 16,22,32$

Both C. vulgaris and C. sorokiniana showed N:P ratios similar to the Redfield ratio of $16: 1$, which is commonly used as a reference for microalgal species ${ }^{33}$ (Table 2). Scenedesmus obliquus, on the other hand, had a lower $\mathrm{N}: \mathrm{P}$ ratio due to its higher $\mathrm{P}$ content. This high $\mathrm{P}$ content can point toward an unusually high P-requirement of this species, or toward a phenomenon called luxury consumption. During luxury consumption a nutrient is taken up at a much higher rate than the actual requirement of the cells, a mechanism that 
Table 2. Dry Biomass Concentration $\left(C_{x}\right) \pm$ Standard Deviation; C, N, and P Molar Ratios and \% in Algal Dry Biomass; and N and P Removal Efficiencies, As Explained in the Calculations Section, at the End of the Experiments (Day 13) from the AnBW, of Three Microalgae Species

\begin{tabular}{|c|c|c|c|c|c|c|c|c|c|}
\hline & \multirow{2}{*}{$\frac{\text { Biomass }}{\mathrm{C}_{x}}$} & \multicolumn{6}{|c|}{ Biomass composition } & \multicolumn{2}{|c|}{ Removal from AnBW } \\
\hline & & $\mathrm{C}$ & $\mathrm{N}$ & $\mathrm{P}$ & $\mathrm{C}$ & $\mathrm{N}$ & $\bar{P}$ & $\mathrm{NH}_{4}^{+}-\mathrm{N}$ & $\mathrm{PO}_{4}-\mathrm{P}$ \\
\hline & $\mathrm{g} \cdot \mathrm{L}^{-1}$ & \multicolumn{6}{|c|}{$\overline{\text { mass fraction (\% of dry biomass) }}$} & \multicolumn{2}{|c|}{$\%$} \\
\hline C. vulgaris & $3.7 \pm 0.2$ & 93 & 16 & 1 & 40 & 7.7 & 1.1 & 26 & 22 \\
\hline C. sorokiniana & $4.3 \pm 0.2$ & 90 & 15 & 1 & 42 & 8.0 & 1.2 & 30 & 39 \\
\hline S. obliquus & $4.4 \pm 0.1$ & 42 & 7 & 1 & 40 & 7.5 & 2.5 & 27 & 93 \\
\hline
\end{tabular}

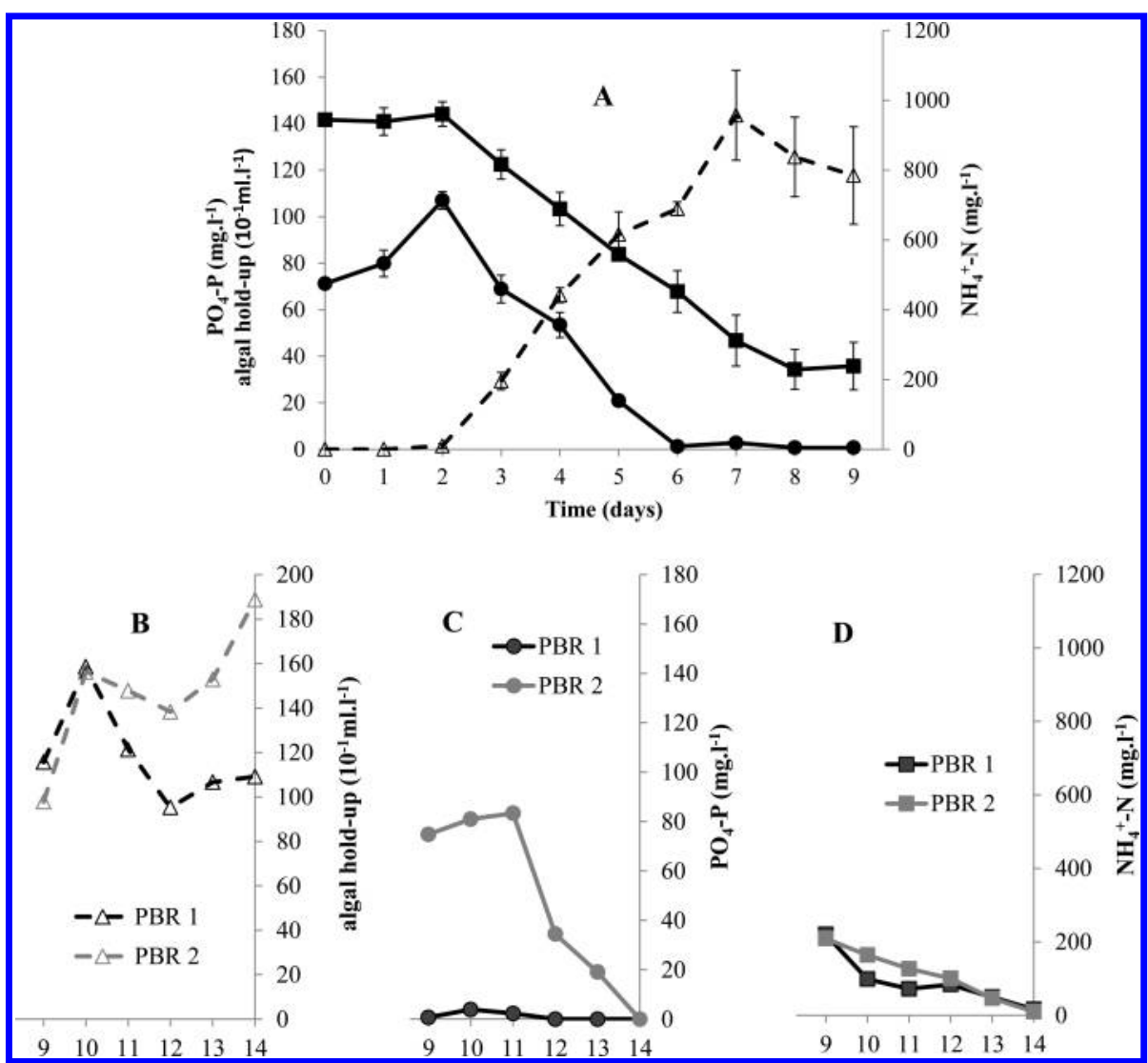

Figure 2. $\mathrm{PO}_{4}-\mathrm{P}(\mathbf{\bullet})$ and $\mathrm{NH}_{4}{ }^{+}-\mathrm{N}(\boldsymbol{\square})$ removal from AnBW by C. sorokiniana and its growth, presented as algal hold-up $(\Delta)$, in time. (A) Results from the three PBR replicates in the first 9 days; (B, C, and D) PBR 1 and PBR 2 results (extra $\mathrm{PO}_{4}-\mathrm{P}$ addition at day 9 ) from day 9 to day 14 . Error bars in plot (A) represent standard deviation between triplicates.

evolved to store nutrients that are occasionally scarce or to consume scarce nutrients faster than competitors. ${ }^{34}$ This high $\mathrm{P}$-content together with the high biomass productivity resulted in $93 \%$ removal of the $\mathrm{PO}_{4}-\mathrm{P}$ by $\mathrm{S}$. obliquus (Table 2), indicating that this species may be very suitable for recovery of $\mathrm{P}$ from wastewaters with high $\mathrm{PO}_{4}-\mathrm{P}$ content, such as olive mill wastewaters. ${ }^{35}$

The carbon content found for the three species, $40-42 \%$ (Table 2), was lower than $46-50 \%$ usually found in the literature. ${ }^{36-38}$ These lower values could be due to a different biochemical composition of the algal biomass grown on AnBW, as it has been reported that differences in macromolecules, such as lipids, may have a relevant effect on the $\mathrm{C}$ content of an organism. $^{39}$

In conclusion, these screening experiments show that various green microalgae can successfully grow on the very nutrientrich AnBW medium, which is favorable for reaching high final biomass concentrations. However, due to the very high ammonia concentrations (about $1 \mathrm{~g} \mathrm{~N} \cdot \mathrm{L}^{-1}$ ) the $\mathrm{N}: \mathrm{P}$ ratio of the AnBW is also very high ( 30:1). This imposes an extra challenge to find the appropriate species, operational conditions, and reactor mode of operation to efficiently reach full $\mathrm{P}$ but also full $\mathrm{N}$ removal. In an effort to reach this, batch experiments in flat-panel PBRs were done, using C. sorokiniana.

$\mathbf{N}$ and $\mathbf{P}$ Removal in Controlled Photobioreactors. Biomass growth together with $\mathrm{PO}_{4}-\mathrm{P}$ and $\mathrm{NH}_{4}{ }^{+}-\mathrm{N}$ removal was followed in three PBR replicates as shown in Figure 2A. From day 9, the second part of the experiment took place, where the replicates were operated as single batches (Figure 2B, $\mathrm{C}$, and D). PBR1 was kept without changes, PBR 2 received extra $\mathrm{PO}_{4}-\mathrm{P}$ addition, and PBR 3 was stopped.

Nutrient Replete Cultivation Phase. A lag phase of approximately 2 days was observed before microalgae growth commenced. During this period, the $\mathrm{PO}_{4}-\mathrm{P}$ concentration increased, which was probably caused by solubilization of the inorganic $\mathrm{PO}_{4}-\mathrm{P}$ from the suspended solids of the AnBW (TP 
Table 3. Biomass Composition, Removal \% and Removal Rates of $\mathrm{NH}_{4}^{+}-\mathrm{N}$ and $\mathrm{PO}_{4}-\mathrm{P}$ from AnBW, Biomass Concentration, and Production Rate and Yield of Biomass on Light Energy of C. sorokiniana at the End of the Linear Growth and End of the Experiment

\begin{tabular}{|c|c|c|c|c|c|}
\hline \multirow[b]{2}{*}{ Description } & \multirow[b]{2}{*}{ Unit } & & \multirow{2}{*}{$\begin{array}{l}\text { Day 2-8 } \\
\text { PBR 1-3 }\end{array}$} & \multicolumn{2}{|c|}{ Day 2-14 } \\
\hline & & & & PBR 1 & PBR 2 \\
\hline \multirow[t]{2}{*}{ Biomass composition } & $\mathrm{mol} \cdot \mathrm{molP}^{-1}$ & $\mathrm{C}: \mathrm{N}: \mathrm{P}$ & n.d. & $125: 19: 1$ & $73: 12: 1^{a}$ \\
\hline & $\%$ & $\mathrm{C}, \mathrm{N}, \mathrm{P}$ & n.d. & $43,7.7,0.9$ & $41,7.4,1.4^{a}$ \\
\hline \multirow[t]{2}{*}{ Removal from AnBW } & $\%$ & $\mathrm{NH}_{4}^{+}-\mathrm{N}$ & $76.1 \pm 6.6$ & 98.4 & 98.9 \\
\hline & & $\mathrm{PO}_{4}-\mathrm{P}$ & 100 & 100 & 100 \\
\hline \multirow[t]{2}{*}{ Removal rates } & $\mathrm{mg} \cdot \mathrm{L}^{-1} \cdot \mathrm{d}^{-1}$ & $\mathrm{NH}_{4}^{+}-\mathrm{N}$ & $121.9 \pm 13.3$ & 81.8 & 76.4 \\
\hline & & $\mathrm{PO}_{4}-\mathrm{P}$ & $16.8 \pm 0.9$ & 8.9 & $14.9^{a}$ \\
\hline Biomass concentration & $\mathrm{g} \mathrm{DW} \cdot \mathrm{L}^{-1 c}$ & & $9.1 \pm 1.0^{b}$ & 10.5 & 12.1 \\
\hline \multirow[t]{2}{*}{ Removal yield on light } & $\mathrm{mg} \mathrm{mol} \mathrm{photon}^{-1}$ & $\mathrm{NH}_{4}^{+}-\mathrm{N}$ & $30.3 \pm 3.4$ & 13.7 & 13.2 \\
\hline & & $\mathrm{PO}_{4}-\mathrm{P}$ & $4.2 \pm 0.2$ & 1.5 & $2.6^{a}$ \\
\hline Yield of biomass on light & $\mathrm{g} \mathrm{mol} \mathrm{photon}{ }^{-1}$ & & $0.4 \pm 0.04$ & 0.15 & 0.17 \\
\hline
\end{tabular}

${ }^{a}$ Values different for PBR 2 in relation to PBR1 due to addition of $75 \mathrm{mg} \mathrm{PO} 4-\mathrm{P} \cdot \mathrm{L}^{-1}$ at day $9 .{ }^{b}$ Estimated from $\mathrm{N}$ removal from day 2 to 8 and final $\mathrm{N}$ content in biomass observed during the screening experiments $(8 \%$, Table 2$) .{ }^{c} \mathrm{DW}=$ dry weight.

of $\left.105.2 \pm 3.9 \mathrm{~g} \cdot \mathrm{L}^{-1}\right)$ as a reaction to the decrease of $\mathrm{pH}$ from 7.5 (AnBW) to 7 (set $\mathrm{pH}$ ), similar to what has been reported earlier in the literature. ${ }^{6}$ The increase of soluble inorganic $\mathrm{PO}_{4}-\mathrm{P}$ was advantageous for a more favorable $\mathrm{N}: \mathrm{P}$ molar ratio of the AnBW (changing it from 30:1 to 20:1).

Once algae growth commenced (day 2), $\mathrm{PO}_{4}-\mathrm{P}$ was finished in 4 days (day 6) at a rate of $26 \mathrm{mg} \cdot \mathrm{L}^{-1} \cdot \mathrm{d}^{-1}$ with a removal yield on light of $12 \mathrm{mg} \mathrm{PO}_{4}-\mathrm{P} \cdot \mathrm{mol}$ photon ${ }^{-1}$. During that same 4-day period, nitrogen removal occurred at a rate of $127 \mathrm{mg}$ $\mathrm{NH}_{4}^{+}-\mathrm{N} \cdot \mathrm{L}^{-1} \cdot \mathrm{d}^{-1}$ with a removal yield on light of $56 \mathrm{mg}$ $\mathrm{NH}_{4}^{+}-\mathrm{N} \cdot \mathrm{mol}$ photon ${ }^{-1}$. The $\mathrm{N}: \mathrm{P}$ removal ratio in these 4 nutrient replete days $(11: 1)$ was much lower than the N:P ratio found for the $C$. sorokiniana during the screening experiments, suggesting that most likely $\mathrm{PO}_{4}-\mathrm{P}$ was being stored as $\mathrm{P}$ reserves within the cells. Indeed, this suggestion is confirmed by a virtually unchanged $\mathrm{NH}_{4}{ }^{+}-\mathrm{N}$ removal rate after $\mathrm{PO}_{4}-\mathrm{P}$ depletion, from day 6 to 8 (Figure 2A). Once the P-reserves were depleted and the N:P removal ratio reached 16:1 (at day 8 ), which is identical to the Redfield ratio and the ratio found for C. sorokiniana in the screening experiments, the $\mathrm{N}$-removal rate decreased substantially from $122 \mathrm{mg} \cdot \mathrm{L}^{-1} \cdot \mathrm{d}^{-1}$ (between day 2 and 8) to $41 \mathrm{mg} \cdot \mathrm{L}^{-1} \cdot \mathrm{d}^{-1}$ (between day 9 and 14) in PBR1 (Figure 2).

Over the 6-day period of constant $\mathrm{N}$ removal (day 2 to 8 ), an $\mathrm{NH}_{4}{ }^{+}-\mathrm{N}$ removal rate of $122 \mathrm{mg} \cdot \mathrm{L}^{-1} \cdot \mathrm{d}^{-1}$ was observed, corresponding to a $\mathrm{N}$ removal yield on light of $30 \mathrm{mg} \mathrm{NH}_{4}^{+}-$ $\mathrm{N} \cdot$ mol photon ${ }^{-1}$. The average $\mathrm{PO}_{4}-\mathrm{P}$ removal rate over this same period was $17 \mathrm{mg} \cdot \mathrm{L}^{-1} \cdot \mathrm{d}^{-1}$, corresponding to a $\mathrm{P}$ removal yield on light of $4.2 \mathrm{mg} \mathrm{PO}_{4}-\mathrm{P} \cdot \mathrm{mol}$ photon ${ }^{-1}$. Based on these $\mathrm{N}$ and $\mathrm{P}$ removal rates, and on the $\mathrm{N}$ and $\mathrm{P}$ contents observed during the screening experiments ( $8 \%$ and $1.2 \%$ respectively, Table 2), the biomass concentration at day 8 was estimated to have been around $9 \mathrm{~g}$ dry weight $\cdot \mathrm{L}^{-1}$. Similarly, the biomass yield on light was estimated at $0.4 \mathrm{~g}$ dry weight $\cdot \mathrm{mol}$ photon ${ }^{-1}$, which is just below the values reported for growth on human urine $\left(0.55 \text { and } 0.7 \mathrm{~g} \text { dry weight } \cdot \mathrm{mol} \text { photon }^{-1}\right)^{18}$ and about half of the optimal values reported for C. sorokiniana. ${ }^{40,41}$ Because the temperature and $\mathrm{pH}$ were kept close to optimal for this species, the low biomass yield in the present experiments is most likely explained by a suboptimal light regime and/or the characteristics of the AnBW. We can however conclude that under nutrient replete conditions $C$. sorokiniana was quite efficient in removing $\mathrm{NH}_{4}^{+}-\mathrm{N}$ and $\mathrm{PO}_{4}-\mathrm{P}$ from AnBW.
However, this efficiency changed when the P-reserves were depleted.

Nutrient-Limited Cultivation Phase: Effect of $P$ Addition. To study, the effect of P-limitation on the nitrogen removal efficiency, $75 \mathrm{mg} \mathrm{PO}_{4}-\mathrm{P} \cdot \mathrm{L}^{-1}$ was added to PBR 2 at day 9 of the experiment. PBR 1 was continued without any changes, and PBR 3 was stopped due to operational problems. This addition did not significantly improve the removal rate of $\mathrm{NH}_{4}{ }^{+}-\mathrm{N}$ from PBR2 compared to PBR1, with both reactors reaching full $\mathrm{N}$ removal at day 14 of the experiment. The nitrogen removal rates between day 9 and 14 were $41 \mathrm{mg} \mathrm{NH}{ }_{4}^{+}-\mathrm{N} \cdot \mathrm{L}^{-1} \cdot \mathrm{d}^{-1}$ for PBR1 and $40 \mathrm{mg} \mathrm{NH}{ }_{4}^{+}-\mathrm{N} \cdot \mathrm{L}^{-1} \cdot \mathrm{d}^{-1}$ for PBR2 (Figure 2).

The lack of effect on $\mathrm{N}$ uptake could have been due to a too late resupply of $\mathrm{PO}_{4}-\mathrm{P}$. Namely, at the moment of replenishment the microalgae had already been deprived of $\mathrm{P}$ for 1 day, which might have forced the cells to enter the stationary phase. Such a physiological state could have resulted in low recovery rates upon P-resupply, resulting in low growth rates and consequently low nutrient removal rates. Indeed, $\mathrm{PO}_{4}-\mathrm{P}$ consumption only started 2 days after P-resupply. Once $\mathrm{PO}_{4}-\mathrm{P}$ consumption commenced at day 11 , the $\mathrm{P}$ removal rate was constant until $\mathrm{P}$ was depleted at day 14 . The $\mathrm{P}$ removal rate during this period was similar to that observed between day 2 and 6 ( 28 vs $26 \mathrm{mg} \mathrm{PO} 4-\mathrm{P} \cdot \mathrm{L}^{-1} \cdot \mathrm{d}^{-1}$, respectively).

The addition of $\mathrm{PO}_{4}-\mathrm{P}$ did however affect cell growth in terms of algal hold-up (Figure 2B). Without this P-addition, the continued $\mathrm{NH}_{4}{ }^{+}-\mathrm{N}$ removal during P-limitation (from day 8 to 14) corresponded to a rather varying algal hold-up, averaging around a $12 \mathrm{~mL}$ cell volume per liter reactor volume which is similar to the hold-up at the onset of P-limitation at day 8 (Figure 2). P-resupply, however, caused the algal hold-up to reach $19 \mathrm{~mL} \cdot \mathrm{L}^{-1}$ at the end of the experiment (Figure 2B). These differences suggest a totally different physiology, despite the similar $\mathrm{N}$ removal rates.

Overall Experiment. The severe drop in removal rates at the onset of P-limitation (at day 8) finally yielded overall nutrient

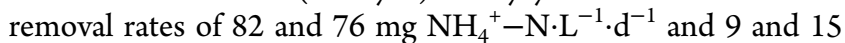
mg $\mathrm{PO}_{4}-\mathrm{P} \cdot \mathrm{L}^{-1} \cdot \mathrm{d}^{-1}$ for PBR 1 and 2 , respectively (Table 3 ). The higher $\mathrm{PO}_{4}-\mathrm{P}$ removal rate for PBR 2 was due to the addition of $\mathrm{PO}_{4}-\mathrm{P}$ at day 9. These overall removal rates corresponded to removal yields on light of $13.5 \mathrm{mg} \mathrm{NH}_{4}^{+}-\mathrm{N}$. mol photon ${ }^{-1}$ and $1.5 \mathrm{mg} \mathrm{PO}_{4}-\mathrm{P} \cdot \mathrm{mol}_{\text {photon }}{ }^{-1}$. The biomass concentration at the end of the experiment reached between 10.5 and $12.1 \mathrm{~g}$ dry weight $\cdot \mathrm{L}^{-1}$ (Table 3 ), which corresponds to 
a quite low biomass yield on light of $0.16 \mathrm{~g}$ dry weight $\cdot \mathrm{mol}$ photon $^{-1}$.

This high final biomass density makes this process attractive for large-scale application, because it will reduce the costs of algae harvesting. On the other hand the low overall yields on light for biomass production and nutrient removal reached will increase photobioreactor investment costs because removal yields on light directly relate to the surface of photobioreactor area required to treat a certain amount of wastewater. A consideration could be to stop the process earlier while the yields on light are still high and use alternative methods for removal of the remaining $\mathrm{N}$, such as partial nitritation and anammox. $^{42}$

In the process described above, for instance, stopping at day 8 would have resulted in a 2.2 -fold higher $\mathrm{NH}_{4}{ }^{+}-\mathrm{N}$ removal yield on light compared to stopping at day 14, with $100 \%$ of the $\mathrm{PO}_{4}-\mathrm{P}$ and $76 \%$ of the $\mathrm{NH}_{4}{ }^{+}-\mathrm{N}$ being removed after these 8 days compared to full removal of both nutrients at day 14 . The estimated biomass concentration at day 8 was about $9 \mathrm{~g}$ dry weight $\cdot \mathrm{L}^{-1}$, which is still favorable for efficient harvesting. Whether the incomplete $\mathrm{N}$-removal is acceptable, or whether the remaining $\mathrm{NH}_{4}{ }^{+}-\mathrm{N}$ can be removed more efficiently than in the process described above, is dependent on the treatment targets and the extent of future improvement of the abovedescribed process.

A possible solution for reaching full $\mathrm{N}$ and $\mathrm{P}$ removal at a faster rate and at a higher yield on light could be to use or add other microalgae with even higher $\mathrm{N}: \mathrm{P}$ uptake ratios. It is known that depending on the growth conditions, algae may obtain N:P ratios that are much higher as compared to the Redfield ratio (16:1). ${ }^{12,43-45}$ More specifically, cellular N:P ratios of algae increase with reduced growth, as well as under resource limitation (particularly P). ${ }^{39,44,46}$ This will be investigated in future experiments.

In conclusion, $C$. sorokiniana can remove all $\mathrm{PO}_{4}-\mathrm{P}$ within 4 days and all $\mathrm{NH}_{4}{ }^{+}-\mathrm{N}$ within 12 days, at the light intensities and photobioreactors used in this experiment. Favorable removal yields were achieved as long as $\mathrm{N}$ and $\mathrm{P}$ did not become limiting. These cultivations resulted in high microalgal biomass concentrations of 10.5 and $12.1 \mathrm{~g} \mathrm{DW} \cdot \mathrm{L}^{-1}$. We believe our findings form a solid basis for further exploration of this technology for full-scale applicability.

\section{AUTHOR INFORMATION}

\section{Corresponding Author}

*Phone: +31-317-473533; e-mail: T.Fernandes@nioo.knaw.nl.

\section{Present Address}

\#Department of Bioscience Engineering Research Group of Sustainable Energy, Air and Water Technology Groenenborgerlaan 171, 2020 Antwerpen, Belgium.

\section{Notes}

The authors declare no competing financial interest.

\section{ACKNOWLEDGMENTS}

We thank Nico Helmsing, Suzanne Wiezer, and Hans Meijer for their technical support. We also like to thank Bas Ibelings and Dedmer van de Waal for useful discussions. Funding came from The Netherlands Enterprise Agency (RVO), Ministry of Economic Affairs, The Netherlands (Innowator project).

\section{REFERENCES}

(1) Zeeman, G.; Kujawa, K.; de mes, T.; Hernandez, L.; De Graaff, M. S.; Abu-Ghunmi, L. N. A. H.; Mels, A. R.; Meulman, B.; Temmink, H.; Buisman, C. J. N.; Van Lier, J. B.; Lettinga, G. Anaerobic treatment as a core technology for energy, nutrients and water recovery from source-separated domestic waste (water). Water Sci. Technol. 2008, 57 (8), 1207-1212.

(2) Zeeman, G.; Kujawa-Roeleveld, K. Resource recovery from source separated domestic waste(water) streams; full scale results. Water Sci. Technol. 2011, 64 (10), 1987-1992.

(3) Cordell, D.; Rosemarin, A.; Schröder, J. J.; Smit, A. L. Towards global phosphorus security: A systems framework for phosphorus recovery and reuse options. Chemosphere 2011, 84 (6), 747-758.

(4) Kujawa-Roeleveld, K.; Zeeman, G. Anaerobic Treatment in Decentralised and Source-Separation-Based Sanitation Concepts. Rev. Environ. Sci. Bio/Technol. 2006, 5 (1), 115-139.

(5) Mihelcic, J. R.; Fry, L. M.; Shaw, R. Global potential of phosphorus recovery from human urine and feces. Chemosphere 2011, 84 (6), 832-839.

(6) de Graaff, M. S.; Temmink, H.; Zeeman, G.; Buisman, C. J. N. Energy and phosphorus recovery from black water. Water Sci. Technol. 2011, 63 (11), 2759-2765.

(7) Wijffels, R. H.; Barbosa, M. J. An Outlook on Microalgal Biofuels. Science 2010, 329 (5993), 796-799.

(8) Mulbry, W.; Westhead, E. K.; Pizarro, C.; Sikora, L. Recycling of manure nutrients: use of algal biomass from dairy manure treatment as a slow release fertilizer. Bioresour. Technol. 2005, 96 (4), 451-458.

(9) Godos, I. d.; Vargas, V. A.; Blanco, S.; González, M. C. G.; Soto, R.; García-Encina, P. A.; Becares, E.; Muñoz, R. A comparative evaluation of microalgae for the degradation of piggery wastewater under photosynthetic oxygenation. Bioresour. Technol. 2010, 101 (14), $5150-5158$.

(10) Levine, R. B.; Costanza-Robinson, M. S.; Spatafora, G. A. Neochloris oleoabundans grown on anaerobically digested dairy manure for concomitant nutrient removal and biodiesel feedstock production. Biomass Bioenergy 2011, 35 (1), 40-49.

(11) Mallick, N. Biotechnological potential of immobilized algae for wastewater N, P and metal removal: A review. BioMetals 2002, 15 (4), 377-390.

(12) Wang, L.; Min, M.; Li, Y.; Chen, P.; Chen, Y.; Liu, Y.; Wang, Y.; Ruan, R. Cultivation of Green Algae Chlorella sp. in Different Wastewaters from Municipal Wastewater Treatment Plant. Appl. Biochem. Biotechnol. 2010, 162 (4), 1174-1186.

(13) Wilkie, A. C.; Mulbry, W. W. Recovery of dairy manure nutrients by benthic freshwater algae. Bioresour. Technol. 2002, 84 (1), $81-91$.

(14) Abeliovich, A. Handbook of microalgal culture, biotechnology and applied phycology; Blackwell Publishing: Oxford, 2005.

(15) Christenson, L.; Sims, R. Production and harvesting of microalgae for wastewater treatment, biofuels, and bioproducts. Biotechnol. Adv. 2011, 29 (6), 686-702.

(16) Pires, J.; Alvim-Ferraz, M.; Martins, F.; Simoes, M. Wastewater treatment to enhance the economic viability of microalgae culture. Environ. Sci. Pollut. Res. 2013, 20 (8), 5096-5105.

(17) Abdel-Raouf, N.; Al-Homaidan, A. A.; Ibraheem, I. B. M. Microalgae and wastewater treatment. Saudi J. Biol. Sci. 2012, 19 (3), 257-275.

(18) Tuantet, K.; Temmink, H.; Zeeman, G.; Janssen, M.; Wijffels, R. H.; Buisman, C. J. N. Nutrient removal and microalgal biomass production on urine in a short light-path photobioreactor. Water Res. 2014, 55 (0), 162-174.

(19) Redfield, A. The biological control of chemical factors in the environment. American Scientist 1958, 46, 205-221.

(20) Bährs, H.; Steinberg, C. Impact of two different humic substances on selected coccal green algae and cyanobacteria-changes in growth and photosynthetic performance. Environ. Sci. Pollut. Res. 2012, 19 (2), 335-346.

(21) Pouneva, I. D. Effect of Humic Substances on the Growth of Microalgal Cultures. Russ. I. Plant Physiol. 2005, 52 (3), 410-413. 
(22) Marcilhac, C.; Sialve, B.; Pourcher, A.-M.; Ziebal, C.; Bernet, N.; Béline, F. Digestate color and light intensity affect nutrient removal and competition phenomena in a microalgal-bacterial ecosystem. Water Res. 2014, 64 (0), 278-287.

(23) Kilham, S.; Kreeger, D.; Lynn, S.; Goulden, C.; Herrera, L. COMBO: a defined freshwater culture medium for algae and zooplankton. Hydrobiologia 1998, 377 (1-3), 147-159.

(24) Breuer, G.; Lamers, P. P.; Martens, D. E.; Draaisma, R. B.; Wijffels, R. H. Effect of light intensity, $\mathrm{pH}$, and temperature on triacylglycerol (TAG) accumulation induced by nitrogen starvation in Scenedesmus obliquus. Bioresour. Technol. 2013, 143 (0), 1-9.

(25) Cuaresma Franco, M.; Buffing, M.; Janssen, M.; Vílchez Lobato, C.; Wijffels, R. Performance of Chlorella sorokiniana under simulated extreme winter conditions. I. Appl. Phvcol. 2012, 24 (4), 693-699.

(26) APHA, Standard Methods for the Examination of Water and Wastewater, 21st ed.; American Public Health Association: Washington DC, 2005.

(27) Fernandes, T. V.; Keesman, K. J.; Zeeman, G.; van Lier, J. B. Effect of ammonia on the anaerobic hydrolysis of cellulose and tributyrin. Biomass Bioenergy 2012, 47, 316-323.

(28) Santos, A. M.; Wijffels, R. H.; Lamers, P. P. pH-upshock yields more lipids in nitrogen-starved Neochloris oleoabundans. Bioresour. Technol. 2014, 152 (0), 299-306.

(29) Cuaresma, M.; Janssen, M.; Vílchez, C.; Wijffels, R. H. Horizontal or vertical photobioreactors? How to improve microalgae photosynthetic efficiency. Bioresour. Technol. 2011, 102 (8), 51295137.

(30) Campbell, D.; Hurry, V.; Clarke, A. K.; Gustafsson, P.; Öquist, G. Chlorophyll Fluorescence Analysis of Cyanobacterial Photosynthesis and Acclimation. Microbiology and Molecular Biology Reviews 1998, 62 (3), 667-683.

(31) Ibelings, B. W.; Kroon, B. M. A.; Mur, L. R. Acclimation of Photosystem II in a Cyanobacterium and a Eukaryotic Green Alga to High and Fluctuating Photosynthetic Photon Flux Densities, Simulating Light Regimes Induced by Mixing in Lakes. New Phytol. 1994, 128 (3), 407-424.

(32) Kim, S.; Park, J. E.; Cho, Y. B.; Hwang, S. J. Growth rate, organic carbon and nutrient removal rates of Chlorella sorokiniana in autotrophic, heterotrophic and mixotrophic conditions. Bioresour. Technol. 2013, 144, 8-13.

(33) Redfield, A. On the proportion of organic derivates in sea water and their relation to the composition of plankton. In James Johnstone Memorial Volume; Daniel, R. J., Ed.; University Press of Liverpool: 1934; pp 177-192.

(34) Powell, N.; Shilton, A. N.; Pratt, S.; Chisti, Y. Factors Influencing Luxury Uptake of Phosphorus by Microalgae in Waste Stabilization Ponds. Environ. Sci. Technol. 2008, 42 (16), 5958-5962.

(35) Kapellakis, I.; Tzanakakis, V. A.; Angelakis, A. N. Land Application-Based Olive Mill Wastewater Management. Water 2015, 7 (2), 362-376.

(36) Kumar, K.; Dasgupta, C. N.; Das, D. Cell growth kinetics of Chlorella sorokiniana and nutritional values of its biomass. Bioresour. Technol. 2014, 167, 358-366.

(37) Bhattacharjee, A.; Ghosh, S. K.; Ghosh, D.; Ghosh, S.; Maiti, M. K.; Sen, S. K. Identification of a heat-stable palmitoyl/oleoyl specific acyl-acyl carrier protein thioesterase in developing seeds of Madhuca butyracea. Plant Sci. 2002, 163 (4), 791.

(38) Tang, D.; Han, W.; Li, P.; Miao, X.; Zhong, J. CO2 biofixation and fatty acid composition of Scenedesmus obliquus and Chlorella pyrenoidosa in response to different $\mathrm{CO} 2$ levels. Bioresour. Technol. 2011, 102 (3), 3071-3076.

(39) Sterner, R. W.; Elser, J. J. Ecological Stoichiometry: The Biology of Elements from Molecules to the Biosphere; Princeton University Press: Princeton, NJ, 2002.

(40) Kliphuis, A. M. J.; de Winter, L.; Vejrazka, C.; Martens, D. E.; Janssen, M.; Wijffels, R. H. Photosynthetic efficiency of Chlorella sorokiniana in a turbulently mixed short light-path photobioreactor. Biotechnol. Prog. 2010, 26 (3), 687-696.
(41) Zijffers, J.-W.; Schippers, K.; Zheng, K.; Janssen, M.; Tramper, J.; Wijffels, R. Maximum Photosynthetic Yield of Green Microalgae in Photobioreactors. Mar. Biotechnol. 2010, 12 (6), 708-718.

(42) de Graaff, M. S.; Temmink, H.; Zeeman, G.; van Loosdrecht, M. C. M.; Buisman, C. J. N. Autotrophic nitrogen removal from black water: Calcium addition as a requirement for settleability. Water Res. 2011, 45 (1), 63-74.

(43) Francoeur, S. N.; Biggs, B. J. F.; Smith, R. A.; Lowe, R. L. Nutrient Limitation of Algal Biomass Accrual in Streams: Seasonal Patterns and a Comparison of Methods. Journal of the North American Benthological Societv 1999, 18 (2), 242-260.

(44) Klausmeier, C. A.; Litchman, E.; Daufresne, T.; Levin, S. A. Optimal nitrogen-to-phosphorus stoichiometry of phytoplankton. Nature 2004, 429 (6988), 171-174.

(45) Loladze, I.; Elser, J. J. The origins of the Redfield nitrogen-tophosphorus ratio are in a homoeostatic protein-to-rRNA ratio. Ecology Letters 2011, 14 (3), 244-250.

(46) Hillebrand, H.; Steinert, G.; Boersma, M.; Malzahn, A.; Meunier, C. L.; Plum, C.; Ptacnik, R. Goldman revisited: Fastergrowing phytoplankton has lower $\mathrm{N}: \mathrm{P}$ and lower stoichiometric flexibility. Limnol. Oceanogr. 2013, 58 (6), 2076-2088. 